\title{
Humanistic Method Dalam Pembelajaran Bahasa Arab
}

\author{
Ela Isnani Munawwaroh ${ }^{1}$ \\ ${ }^{1}$ IAIN Syaikh Abdurrahman Siddik Bangka Belitung
}

\begin{tabular}{ll}
\hline \hline \multicolumn{2}{l}{ Info Artikel : } \\
\hline Diterima & $: 20$ Oktober 2018 \\
Direvisi & $: 13$ November 2018 \\
Dipublish & $: 15$ Desember 2018
\end{tabular}

Kata Kunci :

Metode Humanistik

Pembelajaran Bahasa Arab

Keywords:

Humanistic method

Arabic teaching

\section{Koresponden:}

Ela Isnani Munawwaroh,

Email: elaisnani@iainsasbabel.ac.id

\begin{abstract}
ABSTRAK
Humanisme berkembang selama abad ke-16. Ini memberikan kontribusi untuk pendidikan, hingga pengajaran bahasa. Beberapa ahli telah mengembangkan metode humanistik dalam pengajaran bahasa, yaitu Metode Pembelajaran Konseling (CLM) atau Pembelajaran Bahasa Komunitas (CLL), cara sunyi, sugestopedia dan Total Physical Response (TPR) atau pendekatan pemahaman. Metode ini dapat digunakan dalam pengajaran bahasa sebagai metode alternatif untuk mengajar bahasa Arab.
\end{abstract}

\section{ABSTRACT}

Humanism developed during $16^{\text {th }}$ century. It gives contributions for education, up to language teaching. Some experts have developed humanistic methods in language teaching, they are Counseling Learning Method (CLM) or Community Language Learning (CLL), silent way, suggestopedia and Total Physical Response (TPR) or the comprehension approach. These methods could be used in language teaching as an alternative methods to teach Arabic language.

This is an open access article distributed under the Creative Commons Attribution License, which permits unrestricted use, distribution, and reproduction in any medium, provided the original work is properly cited. (2019 by author.

\section{Pendahuluan}

Metode merupakan salah satu faktor yang mempengaruhi proses pembelajaran. Metode yang tepat akan membantu pelajar dalam memahami pelajaran dengan mudah. Sebaliknya, metode yang salah akan membuat pembelajaran menjadi gagal. Banyak sekali metode yang telah dikemukakan oleh para ahli, baik yang berlandaskan pada pendekatan behavioristik, kognitif maupun pendekatan humanistik. Masingmasing aliran mengunggulkan teori yang mereka kembangkan, meskipun pada akhirnya kita pahami bahwa tidak ada metode yang benar-benar tepat diterapkan untuk setiap proses pembelajaran.

Tulisan ini menjelaskan beberapa metode pembelajaran humanistik yang dikenalkan oleh para ahli untuk pembelajaran bahasa. Metode tersebut kemudian dikaitkan dengan pembelajaran bahasa Arab. Bahasa Arab yang dikenal sebagai bahasa orang Islam, dalam artian bahwa sumber ajaran Islam, yakni Al-Qur'an dan hadist, menggunakan bahasa Arab. Sebagai orang Islam, sudah sepatutnya kita memahami bahasa tersebut untuk lebih memperdalam ajaran agama kita, dikarenakan buku-buku referensi ajaran Islam juga banyak ditulis dalam bahasa Arab. Selain identik sebagai bahasa agama Islam, bahasa Arab juga merupakan salah satu bahasa internasional yang banyak digunakan di negara muslim dan sudah menjadi salah satu bahasa resmi PBB.

Di Indonesia sendiri, bahasa Arab merupakan salah satu mata pelajaran wajib di madrasahmadrasah sejak Madrasah Ibtidaiyah hingga Perguruan Tinggi Agama Islam. Mengingat itu semua, maka upaya untuk memperkenalkan beberapa metode pembelajaran bahasa yang berlandaskan pada pendekatan humanistik sebagai salah satu pendekatan yang mutakhir ini perlu dilakukan. Hal itu sejalan dengan kuatnya ajaran Islam pada diri orang Indonesia khususnya, sehingga menjadi suatu motivasi tertentu untuk mempelajari bahasa Arab.

\section{Pembahasan}

\section{A. Aliran Humanistik, Tokoh dan Teori-teorinya}

Humanistik dapat diartikan sebagai orientasi teoritis yang menekankan kualitas manusia yang unik, khususnya terkait dengan free will (kemampuan bebas) dan potensi untuk mengembangkan dirinya (Rachmahana, 2008). Teori ini muncul sekitar abad ke-16 sebagai bentuk protes terhadap dogma agama seperti tulisan yang ditulis oleh Desiderius Erasmus dan Sir Thomas More yang memprotes gereja yang menyuruh orang taat membuta pada doktrin agama dan merusak kebebasan berpikir (Asyrofi, 2010). 
Di antara tokoh teori humanistik ini adalah Abraham Maslow. Ia menggagas teori baru tentang motivasi yang mengatakan bahwa manusia memiliki enam jenis kebutuhan, yakni kebutuhan fisiologis, kebutuhan akan rasa aman, kebutuhan untuk memiliki-dimiliki, kebutuhan akan cinta, kebutuhan untuk dihargai dan kebutuhan untuk mengaktualisasikan diri (Schunk, 2012). Maslow menekankan bahwa dengan memiliki motivasi yang kuat yang berdasarkan pada kebutuhan manusia itu sendiri, maka seseorang bisa mengembangkan potensinya secara penuh karena seseorang berperilaku disebabkan karena adanya tujuan yang ingin ia capai.

Selanjutnya Carl. R Roger mengutarakan prinsip-prinsip belajar humanistik yang meliputi hasrat untuk belajar, belajar yang berarti, belajar tanpa ancaman, belajar atas inisiatif sendiri dan belajar untuk perubahan.(Yusuf, 2007) Dengan prinsip-prinsip tersebut, seseorang akan memiliki kebermaknaan untuk meningkatkan diri masing-masing temasuk dalam hal belajar.

Berdasarkan pendapat kedua tokoh humanistik tersebut, dapat kita lihat bahwa teori tersebut menekankan pada pembelajaran yang berpusat kepada pelajar. Pelajar secara aktif, mandiri dan bertanggung jawab atas pembelajaran yang dilakukan. Sedangkan peran guru hanya sebagai fasilitator yang melayani kebutuhan domain afektif pelajar.

Oleh karena itu, seorang guru yang baik menurut teori humanisme adalah guru yang memiliki sikap ikhlas dan realitas, percaya dan menghargai kemampuan siswa untuk berkembang meningkatkan dirinya dan memecahkan masalah mereka. Lebih lanjut, selain sebagai fasilitator, guru juga mempunyai fungsi kognitif, manajemen kelas, mempraktektekkan tujuan dan fungsi personal dan inpersonal. Terkait dengan fungsi kognitif, guru berfungsi memproses pengetahuan yang dibutuhkan siswa. Fungsi manajemen kelas; guru bertanggung jawab untuk mengatur materi, jadwal dan teknik pengajaran dan segala sesuatu yang berhubungan dengan proses pembelajaran siswa. Fungsi mempraktekkan tujuan; guru diharapkan mampu mencapai tujuan pembelajaran yang sudah disusun. Dan fungsi personal dan impersonal; guru dituntut untuk memiliki kemampuan dan tanggung jawab untuk menciptakan iklim kelas yang interpersonal (Khalilullah, 2012)

Berdasarkan beberapa teori humanistik di atas, maka dapat kita rangkum prinsip-prinsip belajar humanistik, antara lain:

1. Menunjukkan pengakuan positif pada pelajar.

2. Memberikan pilihan dan kesempatan bagi pelajar untuk mendorong pertumbuhan pribadi mereka.

3. Membantu pelajar dalam melaksanakan pembelajaran dengan memberikan sumber dan dorongan. (Hidayatullah, 2012)

4. Belajar akan berguna jika materi yang dipelajari memiliki kebermaknaan pada diri pelajar. Untuk itu, materi harus relevan dengan kehidupan pelajar sehari-hari.

5. Pembelajaran akan memiliki kebermaknaan dengan melibatkan pelajar secara penuh dalam pembelajaran.

6. Pelajar belajar dalam rasa aman. Semakin besar rasa aman yang dirasakan, maka pelajar akan lebih mudah untuk belajar.

Dari beberapa prinsip belajar humanistik di atas dapat kita lihat bahwa dalam pembelajaran, siswa belajar secara alami, dimana materi yang dipelajari benar-benar memiliki hubungan dengan apa yang mereka butuhkan. Dengan demikian siswa bisa benar-benar merasakan apa yang sedang ia pelajari, apalagi dengan keterlibatan siswa dalam pembelajaran akan semakin meningkatkan hasil belajar mereka, sehingga tujuan pembelajaran akan tercapai.

\section{B. Hakikat Pembelajaran Bahasa Arab}

Bahasa Arab memiliki karakteristik yang membuatnya berbeda dengan bahasa-bahasa lain di dunia. Beberapa karakteristik tersebut antara lain:

1. Abjad bahasa Arab yang tersusun dalam suatu urutan abjad yang kita kenal dengan huruf hijaiyah berbeda dengan bahasa-bahasa lainnya. Misalnya, dalam abjad bahasa Arab terdapat huruf "dhad" yang tidak ditemukan pada bahasa lainnya; (Hermawan, 2011)

2. Penulisan abjad bahasa Arab bisa berubah-ubah sesuai dengan tempat abjad tersebut berada saat membentuk kata. Misalnya, penulisan huruf "sin" atau "w" ketika berada di awal, tengah dan akhir kata. Contoh: شمس , مسيجد , سيوف;

3. Adanya i'rab yaitu pengaturan keadaan akhir kalimat sesuai dengan aturan dalam ilmu nahwu.

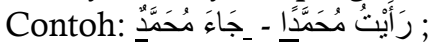


4. Adanya perubahan dan pembentukan kata-kata yang bersumber dari "fi'il madhi" atau "mashdar" ke dalam bentuk yang bermacam-macam yang diatur dalam ilmu sharf. Contoh: سَاجْدُ - يَسْجُدُ - سَجَدَ " - مَنْجِد dan sebagainya.

Oleh karena itu, untuk memiliki kemampuan berbahasa Arab, seseorang pertama-tama harus mengetahui abjad-abjad bahasa Arab yang memiliki keunikan tersebut. Kemudian seseorang tersebut harus mempelajari ilmu nahwu dan sharf. Kedua ilmu ini diperlukan untuk membantu seseorang memperoleh kemahiran berbahasa Arab sesuai dengan tata bahasa yang benar.

Pengajaran bahasa dibagi menjadi dua, yaitu pengajaran bahasa ibu dan pengajaran bahasa asing. Dalam belajar bahasa, kita mengenal empat kemahiran yang harus dikuasai oleh pelajar, yaitu kemahiran istima' (menyimak), kemahiran kalam (berbicara), kemahiran qiroah (membaca) dan kemahiran kitabah (menulis). Kemahiran menyimak dan qiroah disebut dengan kemahiran reseptif dan kemahiran berbicara dan kemahiran menulis disebut dengan kemahiran produktif. Unsur-unsur bahasa Arab sendiri terdiri dari:

1. Huruf-huruf hijaiyah yang merupakan satuan terkecil dalam aksara bahasa Arab.

2. Kata (kalimah) yang dibentuk dalam kaidah sharf. Dalam linguistik, pembentukan kata ini dikenal dengan morfologi. Kata sendiri dalam bahasa Arab dibagi menjadi tiga macam, yaitu kata benda (ism), kata kerja ( $f^{\prime} l$ ) dan huruf (harf).

3. Kalimat (jumlah) yang dipelajari dalam kaidah Nahwu atau dalam linguistik dikenal dengan istilah sintaksis, yaitu menyusun kata-kata di dalam kalimat. (Arsyad, 2010)

Selain ketiga unsur tersebut terdapat beberapa hal yang harus pula dipelajari dalam pembelajaran bahasa yaitu kosakata (mufrodat) dan tarjamah. Hal yang menjadi keunikan bahasa Arab sendiri adalah terdapat ilmu yang mempelajari bagaimana menulis dengan indah yang kita kenal dengan ilmu khath.

Berkenaan dengan hakikat bahasa Arab tersebut, maka pengajaran bahasa Arab harus menggunakan metode yang tepat. Bagi orang Islam sendiri, pengetahuan akan huruf-huruf hijaiyah baik dalam hal membaca maupun menulis, sepatutnya wajib dipelajari karena Al-Qur'an sebagai kitab suci orang Islam menggunakan bahasa Arab. Adanya kewajiban tersebut membantu orang Islam khususnya untuk mempelajari bahasa Arab.

Di Indonesia, bahasa Arab menjadi salah satu bahasa asing yang wajib dipelajari khususnya di madrasah-madrasah hingga Perguruan Tinggi Keagamaan Islam. Pengajaran bahasa Arab juga diwajibkan di pondok-pondok pesantren yang banyak tersebar di Indonesia. Tidak sedikit pondok yang mempelajari kitab-kitab klasik berbahasa Arab yang berisi tentang pengetahuan agama Islam.

\section{Metode-metode Humanistik dalam Pembelajaran Bahasa Arab}

Aliran humanistik turut andil memberikan sumbangsih dalam pembelajaran bahasa dengan mencetuskan beberapa metode pembelajaran bahasa seperti metode counseling learning method (metode belajar konseling/ thariqah at-ta'allum al-irsyadi), silent way (metode guru diam/ ath-thariqah ashshamitah), suggestopedia (metode suggestopedia/ ath-thariqah al-i'aziyyah) dan metode respon ragam total (total physical response). (Hermawan, 2011)Keempat metode tersebut bisa kita terapkan pula dalam pembelajaran bahasa Arab.

1. Counseling Learning Method (Metode Belajar Konseling)

Counseling learning method (CLM) dikenal pula dengan istilah Community Language Learning (CLL) yang berarti belajar bahasa secara komunitas diperkenalkan pertama kali oleh Prof. Charles Curran pada tahun 1961, dan mulai dipakai oleh Loyola Univesity, Chicago, pada tahun 1967. (Hermawan, 2011) Curran merupakan seorang ahli psikologi yang mengambil spesialisasi di bidang penyuluhan (counseling). Dari hasil pengalamannya sebagai konselor inilah yang kemudian membuatnya menciptakan metode belajar konseling ini.

Metode Couseling Learning Method (CLM) merupakan suatu metode yang diterapkan dalam pembelajaran bahasa dengan menekankan peran seorang guru sebagai konselor dan siswa sebagai klien, sehingga dengan fungsi ini, dalam pembelajaran hendaknya guru mampu membantu siswa dalam memenuhi kebutuhan akan pengetahuan yang ia inginkan.

Menurut metode ini, tujuan belajar bahasa adalah untuk meningkatkan kemampuan pelajar dalam menguasai bahasa asing yang dipelajari mendekati penutur asli dan memupuk perasaan harga diri yang tinggi dalam hati pelajar (Himmah, 2018). Selain itu dengan metode ini juga pelajar didorong untuk memiliki rasa tanggung jawab terhadap pembelajaran mereka 
sendiri dan belajar apa yang mereka pelajari, yaitu bagaimana untuk berbicara, sehingga siswa mampu membangun hubungan komunikasi dan menghilangkan ketakutan dalam diri siswa saat ia mempelajari bahasa kedua.

Prinsip metode CLM ini adalah sebagai berikut:

a. Pelajar disebut sebagai "klien" dan guru sebagai "konselor".

b. Hubungan saling percaya dan membantu merupakan hal yang diperlukan dalam proses pembelajaran.

c. "Pelajar-klien" diperbolehkan untuk menggunakan bahasa asli mereka, yang kemudian penerjemahan ke dalam bahasa target akan dibantu "guru-konselor" untuk kemudian mereka praktekkan.

d. Tata bahasa dan kosakata diajarkan secara induktif.

e. Kalimat-kalimat yang dihasilkan oleh pelajar dalam bahasa target direkam untuk kemudian diperdengarkan. Hasil tersebut juga dicatat dengan menggunakan padanan kata dalam bahasa asli untuk menjadi rujukan bagi pelajar.

f. Pelajar menggunakan bahasa target secara bebas tanpa penerjemahan ketika mereka merasa cukup yakin untuk melakukannya.

g. Pelajar didorong untuk tidak hanya mengungkapkan apa yang mereka fikirkan atau pahami tentang bahasa, akan tetapi juga tentang apa yang mereka fikirkan terkait dengan proses belajar, sehingga guru bisa mengungkapkan rasa empati dan mengerti terhadap para pelajar.

h. Bermacam-macam aktifitas bisa dimasukkan dalam proses pembelajaran. Seperti, kegiatan menjelaskan tata bahasa, pengucapan, atau membuat kalimat baru berdasarkan rekaman atau catatan sebelumnya.

Adapun ciri-ciri khas yang secara umum menggambarkan metode Community Language Learning ini adalah adanya penggunaan tape recorder untuk merekam dan memperdengarkan apa yang mereka katakan. Hasil rekaman tersebut kemudian dibuat dalam bentuk transkrip agar bisa digunakan untuk menganalisa kesalahan yang terjadi dalam proses pembelajaran tersebut. Dalam pembelajaran dengan metode CLL ini, klien diberikan kesempatan untuk mengungkapkan apa yang mereka fikirkan. Klien diberikan kesempatan untuk mendengar hasil rekaman suara mereka dan guru bertugas untuk menulis apa saja yang mereka butuhkan agar mereka bisa belajar dari hasil pengalaman belajar mereka. Setelah itu, mereka diberikan kesempatan untuk bekerjasama dalam kelompok-kelompok kecil membuat kalimat baru menggunakan transkrip tersebut yang kemudian diungkapkan kembali dalam proses pembelajaran.

Curran menggambarkan tahapan pembelajaran bahasa oleh pelajar dengan menggunakan metode ini sebagai berikut:

a. Tahap "kelahiran", dimana anak dipupuk untuk menanamkan perasaan "aman" dan "sebagai anggota masyarakat".

b. Tahap "pencapaian kebebasan". Dengan banyaknya pengalaman belajar yang dialami oleh pelajar, ia akan makin bebas dari ketergantungan kepada orang lain.

c. Tahap "berbicara dengan bebas". Pada tahap ini, pelajar mulai menunjukkan identitas dirinya dengan sering menolak nasehat-nasehat orang lain yang tidak diminatinya.

d. Tahap "penerimaan kritik membangun sebagai hal yang dapat diterima". Pada tahap ini anak mulai bisa menerima kritikan dari orang lain untuk memperbaiki kemampuan dirinya.

e. Tahap "peningkatan gaya bahasa dan pengetahuan bentuk-bentuk linguistik yang wajar". Pada tahap ini anak mulai meningkatkan sendiri gaya bahasa dan kemampuan bahasa yang ia miliki(Prihatini, 2014).

Adapun langkah-langkah penggunaan Counseling Learning Method seperti yang dijelaskan dalam buku Acep Hermawan bisa dijelaskan sebagai berikut:

a. Pendahuluan. Guru menyiapkan peralatan yang akan digunakan seperti perekam suara (tape recorder). Kemudian guru membagi para pelajar ke dalam kelompok-kelompok kecil agar pembelajaran lebih efektif.

b. Guru memberikan kesempatan kepada pelajar untuk menentukan topik yang ingin mereka bahas. Setelah melakukan persiapan, mereka diminta untuk merekam suara mereka secara bergiliran. Guru membantu mereka menerjemahkan kalimat yang diminta.

c. Setelah selesai, rekaman tersebut diperdengarkan kembali kepada pelajar ujaran demi ujaran, agar mereka bisa mendengarkannya secara jelas. 
d. Sesudah setiap ujaran diperdengarkan, guru memberikan kesempatan kepada pelajar untuk melakukan pembetulan jika diperlukan.

e. Pada pertemuan berikutnya, rekaman tersebut diperdengarkan kembali dan pelajar diminta untuk menulis transkripsi rekaman tersebut bersama-sama. Kemudian transkripsi tersebut dibaca oleh guru. Selanjutnya guru bisa menentukan struktur bahasa yang harus dipelajari ulang.

f. Dalam mempelajari struktur bahasa tersebut, guru bisa meminta pelajar untuk merubah bentuk kalimat yang telah ia buat ke dalam kalimat lain atau memberikan kosakata yang dibutuhkan oleh pelajar.

g. Pada akhir pembelajaran, guru bisa meminta pelajar untuk mempraktekkan struktur-struktur bahasa secara bebas untuk memantapkan penguasaan materi yang mereka pelajari.

Kelebihan dari metode Counseling Learning Method ini adalah pembelajaran dilakukan dengan learning by doing dimana siswa harus aktif berkomunikasi dengan pelajar lainnya sehingga mampu emningkatkan kemampuan berbahasa mereka secara bertahap. Sedangkan kekurangan dari metode ini adalah tidak bisa dipraktekkan pada kelas besar karena proses pembelajaran dengan metode ini melibatkan pengawasan yang cukup besar pula. Selain itu, dengan banyaknya tema yang muncul dalam proses pembelajaran ini menyebabkan bahwa pembelajaran dengan metode ini tidak cocok dilakukan di sekolah-sekolah yang sudah memiliki kurikulum yang baku.

2. Metode The Silent Way (Guru Diam)

Metode the silent way atau metode guru diam dikenalkan oleh Caleb Gattegno,(Crain, 2014) seorang ahli pengajar bahasa yang menerapkan prinsip-prinsip kognitivisme dalam pembelajaran bahasa. Sesuai dengan namanya, yakni metode guru diam, melibatkan keterlibatan siswa secara aktif dalam pembelajaran, sehingga peran guru di sini hanya memberikan instruksi seperlunya. Selebihnya, pelajar lah yang mengatur pembelajarannya terkait dengan materi yang diberikan.

Adapun prinsip-prinsip dari metode the silent way ini antara lain:

a. Belajar menjadi lebih mudah jika pelajar menemukan sendiri apa yang dipelajari daripada hanya mengingat atau mengulangi apa yang dipelajari. Guru dan siswa adalah partner yang bekerjasama untuk merumuskan apa yang dipelajari.

b. Belajar difasilitasi dengan media pembelajaran yang berupa Media seperti : Sound - Color Chart, Word Chart, Teacher's Silence, Peer Correction dan Rod untuk memfasilitasi ingatan siswa terhadap materi pelajaran.

c. Belajar difasilitasi oleh pemecahan problem yang melibatkan materi yang dipelajari (Himmah, 2018).

Tujuan pembelajaran bahasa melalui metode the silent way ini adalah agar pelajar bisa melatih keterampilan menggunakan bahasa secara lisan, menyimak pembicaraan lawan bicara dan memahami serta menguasai tata bahasa yang praktis.(Crain, 2014)

Dalam proses pembelajaran, guru hanya menjelaskan materi satu kali sehingga hal tersebut memaksa pelajar untuk menyimak dengan baik. Dan selanjutnya, guru lebih banyak diam dan siswalah yang lebih aktif dalam mengucapkan apa yang diminta oleh guru.

Adapun langkah-langkah pembelajaran bahasa melalui metode the silent way ini secara umum adalah sebagai berikut:

a. Guru menyediakan media seperti rod untuk digunakan dalam proses pembelajaran. Media yang digunakan bisa beragam sesuai dengan yang diperlukan.

b. Dalam proses pembelajaran, guru hanya menjelaskan materi sebanyak satu kali. Siswa dituntut untuk memperhatikan dengan baik.

c. Siswa melafalkan simbol yang ditunjuk oleh guru dengan keras secara serentak.

d. Siswa secara satu persatu melafalkan simbol-simbol yang ditunjuk oleh guru sehingga semua siswa memiliki kesempatan untuk aktif dalam pembelajaran.

Kelebihan dari metode the silent way ini adalah sebagai berikut:

a. Penjelasan terkait dengan materi pelajaran hanya diberikan satu kali sehingga memaksa para pelajar untuk menyimak penjelasan dengan baik sejak awal dan mendorong pelajar untuk membuat ujaran-ujaran baru melalui penggabungan materi yang sudah dipelajari.

b. Dengan banyaknya tugas dan aktivitas yang diberikan selama proses pembelajaran, siswa tertuntut untuk aktif sepanjang proses pembelajaran. 
c. Dengan prinsip bahwa guru lebih banyak diam, maka pelajar didorong untuk bisa membuat analogi sendiri berdasarkan kesimpulan materi yang ia pahami (Hermawan, 2011).

Sedangkan kelemahan dari metode ini adalah walaupun Gategno berpendapat bahwa "guru menumpuk otonomi pelajar dengan memberi pilihan-pilihan dalam situasi-situasi yang disajikan", pada kenyataannya gurulah yang menguasai materi dan jalan pengajarannya di kelas. Dengan perkataan lain, kelas masih "berpusat pada guru".

3. Metode Sugestopedia (Suggestopedia)

Metode sugestopedia dikembangkan oleh seorang Psikiatri dan pendidikan Bulgaria, Georgi Lozanov. Lozanov mempercayai bahwa otak manusia memiliki kemampuan belajar yang hebat, akan tetapi kekhawatiran dan rasa takut gagal pada diri seseorang menjadi objek penghalang untuk mencapai potensi tersebut (Rahman, 2015) Untuk itu, Lazanov menciptakan metode sugestopedia yang memiliki cara kerja dengan menstimulasi otak dengan memanfaatkan pembelajaran menggunakan musik, seni, relaksasi, meditasi, bunga, lingkungan yang berwarna, imajinasi, fantasi dan lain-lain yang bisa memberikan stimulasi positif bagi otak.

Prinsip-prinsip dari metode tersebut antara lain:

a. Penekanan bahwa belajar itu mudah dan menyenangkan

b. Perpaduan antara faktor sadar dan faktor di bawah sadar pelajar

c. Interaksi yang hidup antar pelajar untuk memberikan kesan yang bermakna pada diri mereka (Nababan, 1993).

Adapun penerapan metode sugestopedia ini memiliki aturan sebagai berikut:

a. Pada tahap pertemuan pertama, guru menyajikan materi yang terkait dengan kegiatan lisan seperti dialog, cerita pendek dan lainnya.

b. Pada tahap pertemuan selanjutnya, guru menyajikan materi yang terkait dengan kegiatan menyimak dan berbicara.

Sedangkan langkah-langkah penyajiannya meliputi:

a. Pertama-tama guru memberikan ulasan materi yang telah dipelajari sebelumnya untuk memancing kembali pemahaman pelajar terhadap materi yang telah diajarkan.

b. Guru menyajikan materi baru dengan penjelasan tata bahasa dan terjemahan yang relevan.

c. Guru memberikan waktu satu jam untuk pertemuan santai dan meditasi yang menjadi keunikan dari metode ini (Nababan, 1993)

Maksud dari meditasi ini adalah pelajar diberikan kesempatan untuk duduk santai sambil mendengarkan materi yang sudah dijelaskan dengan latar belakang musik lembut untuk membuat suasana kelas menjadi lebih santai. Yoga dan latihan pernafasan secara dalam dan ritmis juga menjadi salah satu bentuk kegiatan untuk membantu siswa mencapai rasa santai dan nyaman sehingga menumbuhkan konsentrasi pelajar.

Kelebihan dari metode ini adalah dengan pelajar yang berjumlah maksimal 12 orang akan menambah suasana kelas menjadi lebih santai sehingga pelajar tidak merasa terkekang. Jumlah yang sedikit ini pula akan lebih membantu proses pembelajaran, karena fokus guru dan kerjasama antar pelajar menjadi lebih mudah dilakukan. Sedangkan kelemahannya adalah dengan sedikitnya jumlah pelajar dalam satu kelas membuat metode tersebut hanya cocok dilakukan pada pembelajaran bahasa dengan jumlah pelajar sedikit sehingga tidak cocok dilakukan di sekolah-sekolah di Indonesia pada umumnya yang memiliki jumlah pelajar yang cukup banyak untuk setiap kelasnya. Namun, bukan berarti metode ini tidak bisa diterapkan.

4. Metode Respon Raga Total (Total Physical Response/TPR)

Metode respon raga total/total physical response (TPR) dicetuskan oleh James J. Asher, seorang ahli psikologi di salah satu universitas di Amerika Serikat. Metode ini berpijak pada pengajaran bahasa melalui aktivitas psikomotorik (Izzan, 2014). Dalam artian bahwa siswa aktif memperagakan bahasa yang diajarkan oleh guru dalam gerakan fisik. Metode ini disebut pula dengan "the comprehension approach" yang menekankan pentingnya "listening comprehension".

Adapun langkah-langkah pembelajaran bahasa dengan metode respon raga total adalah sebagai berikut: 
a. Guru memberikan contoh-contoh perintah yang akan dajarkan kepada siswa yang diikuti dengan peragaan secara fisik setiap perintah yang diajarkan.

b. Guru meminta siswa untuk memberikan tanggapan secara fisik atas perintah yang diberikan oleh guru sesuai dengan contoh yang diberikan sebelumnya.

c. Kegiatan tersebut dilakukan secara berulang-ulang agar apa yang dipelajari tertanam dalam ingatan siswa (Tungka, 2017).

\section{Kesimpulan}

Aliran Humanistik memberikan perhatian pada kualitas manusia yang memiliki kemauan bebas dan potensi untuk mengembangkan dirinya. Karena itu, metode pembelajaran yang diturunkan dari aliran ini berfokus pada diri siswa sebagai pembelajar. Metode pembelajaran bahasa dalam aliran humanistik yang bisa diterapkan dalam pembelajaran bahasa Arab antara lain metode counseling learning method (metode belajar konseling/ thariqah at-ta'allum al-irsyadi), silent way (metode guru diam/ ath-thariqah ash-shamitah), suggestopedia (metode suggestopedia/ ath-thariqah al-i'aziyyah) dan metode respon ragam total (total physical response).

\section{Referensi}

Arsyad, A. (2010). Bahasa Arab dan Metode Pengajarannya. Yogyakarta: Pustaka Pelajar.

Asyrofi, S. (2010). Metodologi Pembelajaran Bahasa Arab. Yogyakarta: Idea Press.

Crain, W. (2014). Teori Perkembangan (Konsep dan Aplikasi) (II). Yogyakarta: Pustaka Pelajar.

Hermawan, A. (2011). Metodologi Pembelajaran Bahasa Arab. Bandung: PT. Remaja Rosdakarya.

Hidayatullah, M. S. (2012). Cakrawala Linguistik Arab. Tangerang: alkitabizz.

Himmah, C. F. (2018). Penerapan Metode Total Physical Response (TPR) Untuk Pemahaman Kalimat Bahasa Jepang. Fakultas Pendidikan Bahasa Universitas Muhamadiyah Yogyakarta.

Izzan, A. (2014). Metodologi Pembelajaran Bahasa Inggris. Bandung: Humaniora.

Khalilullah, M. (2012). Media Pembelajaran Bahasa Arab. Yogyakarta: Aswaja Pressindo.

Nababan. (1993). Metodologi Pengajaran Bahasa. Jakarta: Pustaka Utama.

Prihatini, D. A. (2014). Penggunaan Metode Silent Way Dalam Pengajaran Bahasa Inggris Di Piaenglish Course Manado. Jurnal Elektronik Fakultas Sastra Universitas Sam Ratulangi, 2(1).

Rachmahana, R. S. (2008). Psikologi Humanistik dan Aplikasinya dalam Pendidikan. El-Tarbawi, I(1), 99114.

Rahman, M. (2015). "Humanistic Approaches" to Language Teaching: from Theory to Practice. Stamford Journal of English. https://doi.org/10.3329/sje.v4i0.13491

Schunk, D. H. (2012). Learning Theories: an Educational Perspective. Yogyakarta: Pustaka Pelajar.

Tungka, N. F. (2017). Penerapan Metode Total Physical Response Dan Mind Mapping Dalam Pengajaran Bahasa Inggris Di Tk Kemala Bhayangkari. (October 2011). https://doi.org/10.13140/RG.2.2.18557.15842

Yusuf, S. (2007). Teori Kepribadian. Bandung: PT. Remaja Rosdakarya. 